\title{
Can the Electrophysiological Action of Rosiglitazone Explain its Cardiac Side Effects?
}

\author{
A. Szebeni ${ }^{1}$, N. Szentandrássy ${ }^{2}$, P. Pacher ${ }^{3}$, J. Simkó4 ${ }^{4}$ P.P. Nánási ${ }^{2}$, and V. Kecskeméti ${ }^{\star}, 1$ \\ ${ }^{1}$ Department of Pharmacology and Pharmacotherapy, Semmelweis University, Budapest, \\ Hungary \\ ${ }^{2}$ Department of Physiology, University of Debrecen, Hungary \\ ${ }^{3}$ Laboratory of Physiologic Studies, National Institute on Alcohol Abuse and Alcoholism, \\ Bethesda, USA \\ ${ }^{4}$ Department of Cardiology, Institute of Medicine, Semmelweis Health Care Center, Miskolc, \\ Hungary
}

\section{Abstract}

Recent large clinical trials found an association between the antidiabetic drug rosiglitazone therapy and increased risk of cardiovascular adverse events. The aim of this report is to elucidate the cardiac electrophysiological properties of rosiglitazone $(\mathrm{R})$ on isolated rat and murine ventricular papillary muscle cells and canine ventricular myocytes using conventional microelectrode, whole cell voltage clamp, and action potential (AP) voltage clamp techniques.

In histidine-decarboxylase knockout mice as well as in their wild types $\mathrm{R}(1-30 \mu \mathrm{M})$ shortened AP duration at $90 \%$ level of repolarization ( $\mathrm{APD}_{90}$ ) and increased the AP amplitude (APA) in a concentration-dependent manner. In rat ventricular papillary muscle cells $\mathrm{R}(1-30 \mu \mathrm{M})$ caused a significant reduction of APA and maximum velocity of depolarization $\left(\mathrm{V}_{\max }\right)$ which was accompanied by lengthening of $\mathrm{APD}_{90}$.

In single canine ventricular myocytes at concentrations $\geq 10 \mu \mathrm{M} R$ decreased the amplitude of phase-1 repolarization, the plateau potential and reduced $\mathrm{V}_{\max }$. $R$ suppressed several ion currents in a concentration-dependent manner under voltage clamp conditions. The $\mathrm{EC}_{50}$ value for this inhibition was $25.2 \pm 2.7 \mu \mathrm{M}$ for the transient outward $\mathrm{K}^{+}$current $\left(\mathrm{I}_{\mathrm{to}}\right), 72.3 \pm 9.3 \mu \mathrm{M}$ for the rapid delayed rectifier $\mathrm{K}^{+}$current $\left(\mathrm{I}_{\mathrm{Kr}}\right)$, and $82.5 \pm 9.4 \mu \mathrm{M}$ for the L-type $\mathrm{Ca}^{2+}$ current $\left(\mathrm{I}_{\mathrm{Ca}}\right)$ with Hill coefficients close to unity. The inward rectifier $\mathrm{K}^{+}$current $\left(\mathrm{I}_{\mathrm{K} 1}\right)$ was not affected by $\mathrm{R}$ up to concentrations of $100 \mu \mathrm{M}$. Suppression of $\mathrm{I}_{\mathrm{to}}, \mathrm{I}_{\mathrm{Kr}}$, and $\mathrm{I}_{\mathrm{Ca}}$ has been confirmed under action potential voltage clamp conditions as well.

The observed alterations in the AP morphology and densities of ion currents may predict serious proarrhythmic risk in case of intoxication with $\mathrm{R}$ as a consequence of overdose or decreased elimination of the drug, particularly in patients having multiple cardiovascular risk factors, such as elderly diabetic patients.

\section{Keywords}

Antidiabetic agents; rosiglitazone; action potential; ion currents

\footnotetext{
(C) 2011 Bentham Science Publishers Ltd.

*Address correspondence to this author at the Department of Pharmacology and Pharmacotherapy, Semmelweis University, Budapest, Nagyvárad tér 4, P.O.B.370, 1445 Hungary; Tel: +36-1-2104416; Fax: +36-1.2104412; kecsval@ pharma.sote.hu.
} 


\section{INTRODUCTION}

Diabetes mellitus is associated with increased risk of cardiovascular disease sometimes resulting in sudden cardiac death. Patients with diabetes mellitus exhibit a high incidence of diabetic cardiomyopathy, characterized by complex changes in the electrical and mechanical properties of the heart $[1,2]$. The most prominent electrical alteration is the prolongation of the QTc interval and increased QTc dispersion. In the isolated cardiomyocytes of diabetic rats, significant prolongation of APD and reduction of $\mathrm{K}^{+}$currents were reported $[3,4]$. Cardiac $\mathrm{K}^{+}$currents $\left(\mathrm{I}_{\mathrm{to}}, \mathrm{I}_{\mathrm{Ks}}\right.$, and the steady-state outward current, $\mathrm{I}_{\mathrm{ss}}$ ) are regulated in a complex manner and its amplitude or density depends on several factors such as cell type, age, species, pathological state of the heart, and various neurohormonal factors. Reduction of these currents has been associated with altered action potential profiles in diabetic heart models [4-6].

As the incidence of type 2 diabetes mellitus (T2DM) continues to increase, the World Health Organization predicts approximately 300 million cases worldwide by the year 2010. During the selection of the most appropriate antidiabetic drug for the T2DM patients, the benefit/ risk ratio (benefits versus side effects) of the chosen compounds beyond the individual state of the patient should be considered. Recently two widely used thiazolidinediones (TZDs) rosiglitazone and pioglitazone - became well-established elements of treatment algorithm of T2DM [7]. These drugs, by increasing insulin sensitization, result in a strong and long lasting improvement of glycemic control which may be related to their potential $\beta$-cell preserving properties [8-10]. In spite of multiple beneficial effects of these drugs several large scale clinical trials associated thiazolidinedione therapy with adverse cardiovascular (CV) consequences (weight gain, edema, heart failure) [11-14]; and in the case of rosiglitazone an increased risk of acute myocardial infarction was also observed [15]. This latter risk of rosiglitazone therapy resulted in the suspension or restricted access to rosiglitazone in some countries [16, 17].

We hypothesized that rosiglitazone may adversely affect electrophysiological properties of the heart, thus we aimed to study the effects of the drug on action potential morphology in three different mammalian (mouse, rat, and canine) cardiac preparations.

\section{GENERAL OVERVIEW OF THIAZOLIDINEDIONES}

TZDs, including pioglitazone and rosiglitazone, are oral antidiabetic drugs for the treatment of T2DM. Their chemical structure is presented in Fig. (1). TZDs are high affinity ligands for the nuclear receptor peroxisome-proliferator-activated receptor $\gamma(\operatorname{PPAR} \gamma)[18,19]$ which regulates genes involved in the metabolism of glucose and fat. PPAR $\gamma$ regulates a diverse array of physiological processes including adipogenesis, lipid metabolism, and insulin sensitivity, as well as an important player in the pathogenesis of diseases such as obesity, diabetes, and atherosclerosis [20, 21, 22, 23]. Among TZDs the full PPAR $\gamma$ agonist rosiglitazone and pioglitazone have been widely used in clinical practice, while others (e.g. troglitazone) were discontinued due to their hepatotoxicity [19, 24]. To separate the desirable, beneficial and adverse negative side effects of the currently available PPAR $\gamma$ agonists, several drug-discovery programs have attempted to identify PPAR $\gamma$ partial agonists having appropriate antidiabetic efficacy with less adverse actions [25-27]. Chemical structures of some representative partial PPAR $\gamma$ agonists are shown in Fig. (2). Balaglitazone is a novel thiazolidinedione under clinical development for the treatment of T2DM. Balaglitazone is a selective partial agonist of PPAR $\gamma$, with similar antihyperglycemic efficacy to that of rosiglitazone, but less pronounced body fluid retention properties than rosiglitazone [25]. Compound 50 and MK-0533 are partial PPAR $\gamma$ agonists 
being in preclinical phase of development, both exerting marked antidiabetic activity with less adverse effects [26, 27].

\section{CARDIOVASCULAR EFFECTS OF THE MOST COMMONLY USED TZDS}

These drugs improving the insulin-sensitivity in adipose tissue and skeletal muscle stimulate the expression and function of glucose transporters in the myocardium, resulting in improved glucose metabolism by the heart [28-33].

Beyond improving glycemic control, TZDs may provide some other therapeutic benefits including vasorelaxant, antihypertensive, anti-inflammatory effects [34-38].

Both rosiglitazone and pioglitazone are known to modify the lipid profile as well. Rosiglitazone increases low-density lipoprotein cholesterol (LDL-C) concentration, increases the number of atherogenic (i.e. apo B100-containing) particles and tends to raise triglycerides, whereas pioglitazone is neutral with respect to LDL-C levels, tends to lower apo B100, and reduces plasma triglyceride levels $[39,40]$.

Among these, TZDs improve markers of inflammation (e.g. C-reactive protein, CRP), influence components of the coagulation cascade (e.g. plasminogen activator inhibitor-1, PAI-1), and increase levels of the anti-atherosclerotic adipokine and adiponectin [41-44]. They also modulate macrophage foam cell formation, plaque stability, the response to vascular injury, and improve endothelial function and microalbuminuria [45, 46]. Studies in animal models also demonstrate their ability to improve outcomes after experimentally induced myocardial infarction (MI) or stroke [47-49]. In human studies, they also improve cardiac performance, and pioglitazone has been shown to reduce the progression of carotid intima-media thickness, which is a well-established surrogate for atherosclerosis [50, 51]. Indeed, pioglitazone was shown to reduce the progression of atherosclerosis, as measured using intravascular ultrasound, and to improve CV risk factors over 18 months, whereas there was a progression of coronary atherosclerosis with glimepiride [52].

\section{CLINICAL EVIDENCES}

Based on multiple effects (on glycemia, lipid profile, blood pressure, biomarkers) of TZDs it is assumed that these drugs reduce micro- and macrovascular complications of T2DM. Unfortunately, several large scale clinical studies reported that thiazolidinedione therapy was associated with cardiovascular complications [11, 12], including their propensity to cause edema (and subsequently symptoms of heart failure), weight gain, and increased risk of myocardial infarction [13-15, 53, 54]. It is not easy to confirm the effects of TZDs which are responsible for heart failure (HF). Patients with T2DM are already at increased risk for $\mathrm{HF}$ and other adverse $\mathrm{CV}$ events and it would be a cause for concern if this risk was increased further by glucose-lowering therapy.

TZDs have a number of effects that are of potential benefit to patients with HF, including blood pressure lowering, angiotensin II reduction, endothelial function and lipid profile improvement, and slowing of atherosclerosis progression [50, 55, 56]. However, TZDs also increase sodium reabsorption in the distal nephron $[57,58]$ leading to fluid retention and peripheral oedema, which may be of particular concern in patients with HF [59]. Several meta-analyses have indicated that pioglitazone and rosiglitazone use in T2DM increases the risk of HF $[60,61]$ recommending caution in prescribing TZDs to patients with NYHA class I-II HF and completely avoiding TZDs in patients with NYHA class III-IV HF [62].

While a number of randomised controlled trials have indicated that both rosiglitazone and pioglitazone enhance the risk of HF, the increased risk of acute myocardial infarction and 
mortality appeared to be limited to rosiglitazone [15, 63] but not to pioglitazone [64, 65]. In spite of the fact that these latter risks of rosiglitazone therapy were not confirmed by other clinical studies $[66,67]$ restricted access to rosiglitazone was introduced in some countries $[16,17]$.

It remains to be elucidated, however, what is the explanation for the differences found between the effects of rosiglitazone and pioglitazone on $\mathrm{CV}$ outcomes despite their similar effects on glycemic control.

\section{CELLULAR ELECTROPHYSIOLOGICAL EFFECTS OF TZDs}

The very limited data concerning the direct cardiac effects of rosiglitazone in experimental conditions may explain its cardiac side effects. Rosiglitazone was shown to attenuate porcine action potential shortening induced both during ischemia and by the $\mathrm{K}_{\mathrm{ATP}}$ channels opener levocromocalim [68]. Moreover, rosiglitazone increased the propensity of ventricular fibrillation in pigs, which effect was attributed to inhibition of the cardiac ATP-sensitive $\mathrm{K}^{+}$ channels [68]. This presumed rosiglitazone-resulted reduction of the protective role of ischemia-induced $\mathrm{K}_{\mathrm{ATP}}$ channels activation might explain its property for inducing higher incidence of myocardial ischemia. Furthermore, rosiglitazone was shown to block a wide variety of non cardiac ion channels, including neuronal $\mathrm{Ca}^{2+}$ channels, epithelial $\mathrm{Na}^{+}$ channels, ATP-sensitive $\mathrm{K}^{+}$channels, delayed rectifier $\mathrm{K}^{+}$channels, and L-type $\mathrm{Ca}^{2+}$ channels in aortic smooth muscle cells [69-72]. In contrast to the lack of data on cardiac cells with rosiglitazone, another thiazolidinedione derivative, troglitazone was shown to effectively block L-type $\mathrm{Ca}^{2+}$ current in ventricular myocytes of guinea pigs [73, 74] and rats $[75,76]$, while in rabbit ventricular cells $\mathrm{Na}^{+}, \mathrm{Ca}^{2+}$, and $\mathrm{K}^{+}$currents were suppressed by the drug [77].

\subsection{Effect of Rosiglitazone on Action Potential Configuration}

In this study we demonstrate that rosiglitazone exerts complex, very diverse (sometimes similar, sometimes different) electrophysiological actions in small rodent ventricular papillary muscles and canine ventricular cardiomyocytes. Nearly in all of the preparations studied - except for histidine decarboxylase knockout (HDC-KO) mice (Fig. 4C) rosiglitazone caused a significant concentration dependent reduction of $\mathrm{V}_{\max }$ (Fig. 3C, 4C, 5C), an indirect indicator of $\mathrm{Na}^{+}$current $\left(\mathrm{I}_{\mathrm{Na}}\right)$ density [78]. Rosiglitazone exerted a concentration dependent depression of APA in rats (Fig. 3A), but an increase in APA was observed in wild type as well as in HDC-KO mice (Fig. 4A). In case of canine myocytes, in spite of the reduction of $\mathrm{V}_{\max }$, APA was not decreased; in contrast, it was significantly increased by $100 \mu \mathrm{M}$ rosiglitazone (Fig. 5E).

Action potential duration, especially during the most terminal phase of repolarization was also affected. $\mathrm{APD}_{90}$ was shortened in mice (Fig. 4B), while it was prolonged in rat (Fig. $3 \mathrm{~B})$ in a concentration-dependent manner. In canine myocytes $\mathrm{APD}_{90}$ was significantly shortened by $30 \mu \mathrm{M}$ rosiglitazone, while it was lengthened by high concentrations (Fig. 5B).

Concerning our results obtained in rats, our $\mathrm{V}_{\max }$ data are similar to data of Kavak et al. [79], while the effects of rosiglitazone on $\mathrm{APD}_{90}$ and APA show apparently interspecies differences. These differences can probably be explained by differences in AP morphology and in the kinetic properties of the rat, murine and canine $\mathrm{K}^{+}$currents active during ventricular repolatization (over-exposed $\mathrm{I}_{\mathrm{to}}$, absence of plateau phase in rats and mice) [80]. Another possible explanation for the differences seen with the HDC-KO group might be the fact that these animals are more susceptible to auto-immune diabetes development. Histidine decarboxylase knockout mice lack endogenous histamine, and they are characterized by impaired glucose tolerance. Furthermore, they have autoantibodies reactive to glutamic acid 
decarboxylase (GAD), a possible target-antigen of the diabetogenic autoimmune process [81]. Our previous data showed that electrophysiological changes relevant to diabetes (i.e. prolongation of repolarization and depression of $\mathrm{V}_{\max }$ ) developed in these animals without any diabetes induction [82]. These characteristics can be observed in the present study on Fig. (4), where in HDC-KO control group APD $\mathrm{AP}_{90}$ was lengthened (Fig. 4B) and $\mathrm{V}_{\max }$ was depressed (Fig. 4C) comparing to the control values of the wild type animals (Fig. 4B, 4C). Whereas direct ionic current measurements in the case of rats and mice were not performed, the results suggest that rosiglitazone can alter the activity of some cardiac ion channels. This suggestion was supported by data from murine diabetic model showing that chronic treatment of rosiglitazone could modify expression of genes for $\mathrm{K}^{+}$channel/channel interacting proteins [83].

\subsection{Effect of Rosiglitazone on the Density of Cardiac lon Currents Measured by Conventional Voltage Clamp}

The effects of rosiglitazone on native cardiac ion currents were analysed in canine cardiac myocytes. In these experiments, performed under conventional voltage clamp conditions, cumulative concentration-dependent drug-effects were monitored between 1 and $300 \mu \mathrm{M}$, increasing the concentration of rosiglitazone usually in steps of $0.5 \log$ units. Kinetic properties of the channel gating were studied at concentrations which were close to the half effective blocking concentration of rosiglitazone on the given ion current. The results revealed that rosiglitazone suppressed several ion currents in a concentration-dependent manner with the concomitant alterations in action potential configuration. For instance, the rosiglitazone-induced decrease canine phase-1 repolarization is explained by the reduction of $\mathrm{I}_{\text {to }}$ with an $\mathrm{EC}_{50}$ value of $25.2 \pm 2.7 \mu \mathrm{M}$ (Fig. 6A). Similarly, the plateau-depression, observed in the presence of rosiglitazone in Fig. (5), may be a consequence of inhibition of $\mathrm{Ca}^{2+}$ and $\mathrm{Na}^{+}$currents. Concentration-dependent blockade of $\mathrm{I}_{\mathrm{Ca}}$, characterized by an $\mathrm{EC}_{50}$ of 82.5 $\pm 9.4 \mu \mathrm{M}$, was demonstrated in voltage clamp experiments (Fig. 6C), while the observed suppression of $\mathrm{V}_{\max }$ is believed to be a good indicator of $\mathrm{I}_{\mathrm{Na}}$ blockade [78]. As shown in Fig. (6B), the amplitudes of the $\mathrm{I}_{\mathrm{Kr}}$ current tails were also progressively decreased by increasing concentrations of rosiglitazone, having an $\mathrm{EC}_{50}$ value of $72.3 \pm 9.3 \mu \mathrm{M}$. While the blocking actions of rosiglitazone on $\mathrm{I}_{\mathrm{to}}$ and $\mathrm{I}_{\mathrm{Kr}}$ developed rapidly and were fully reversible, suppression of $\mathrm{I}_{\mathrm{Ca}}$ was only partially reversible upon washout. $\mathrm{I}_{\mathrm{K} 1}$ was not significantly modified by rosiglitazone up to the concentration of $100 \mu \mathrm{M}$. At a concentration of $300 \mu \mathrm{M}$ a small but fully reversible suppression of $\mathrm{I}_{\mathrm{K} 1}$ was observed. Our data on potency of inhibition of $\mathrm{I}_{\mathrm{to}}$ was supported by recent results of Jeong and coworkers [84] who found that rosiglitazone inhibits recombinant $\mathrm{K}_{\mathrm{v}} 4.3$ channels current with an $\mathrm{IC}_{50}$ of $25 \mu \mathrm{M}$ which is in strong agreement with our finding.

In spite of the multiple actions of rosiglitazone on canine cardiac ion channels, its effect on action potential configuration is relatively well compensated. For instance, action potential duration was little affected by rosiglitazone (except for the moderate shortening of $\mathrm{APD}_{50}$ at $30 \mu \mathrm{M}$ and lengthening of $\mathrm{APD}_{90}$ at $\left.100 \mu \mathrm{M}\right)$. This is the consequence of simultaneous blockade of inward (window $\mathrm{I}_{\mathrm{Na}}$ and $\mathrm{I}_{\mathrm{Ca}}$ ) and outward $\left(\mathrm{I}_{\mathrm{Kr}}\right.$ and $\mathrm{I}_{\mathrm{to}}$ ) currents during the plateau. Suppression of $\mathrm{V}_{\max }$ is usually accompanied with reduction of APA. This effect was not observed in canine myocytes with rosiglitazone - in contrast - APA was significantly increased by $100 \mu \mathrm{M}$ rosiglitazone. This is likely due to the simultaneous blockade of $\mathrm{I}_{\mathrm{Na}}$ and $\mathrm{I}_{\mathrm{to}}$, from which the earlier tends to decrease, while the latter tends to increase the amplitude of action potentials. Finally, the lack of depolarization is in line with the inability of rosiglitazone to alter $\mathrm{I}_{\mathrm{K} 1}$ at concentrations not higher than $100 \mu \mathrm{M}$.

The present results allow some comparison between the cellular cardiac electrophysiological effects of rosiglitazone and troglitazone. Troglitazone blocked $\mathrm{I}_{\mathrm{Ca}}$ with $\mathrm{IC}_{50}$ values close to $10 \mu \mathrm{M}$ in rat [75, 76], rabbit [77] and guinea pig myocytes [73]. This value is significantly 
smaller than the $\mathrm{IC}_{50}$ of $92 \mu \mathrm{M}$ obtained with rosiglitazone in canine ventricular cells (present study). The inhibitory effect of troglitazone on $\mathrm{I}_{\mathrm{Na}}$ is also much stronger than that of rosiglitazone. In contrast to our results, where $100 \mu \mathrm{M}$ rosiglitazone caused less than 50 $\%$ reduction of $\mathrm{V}_{\max }, 1 \mu \mathrm{M}$ of troglitazone induced $50 \% \mathrm{~V}_{\max }$-blockade, while $10 \mu \mathrm{M}$ of the compound fully eliminated action potentials in rabbit ventricular myocytes [77]. Thus the difference between the inhibiting potency of rosiglitazone and troglitazone seems to be at least one order of magnitude.

\subsection{Effect of Rosiglitazone on Ion Currents Under Action Potential Clamp Conditions}

The profile of an ion current may be markedly different when comparing under conventional voltage clamp and action potential clamp conditions [85]. An advantage of the action potential clamp technique is that the effect of any drug on the net membrane current can be recorded allowing thus to monitor drug-effects simultaneously on more than one ion current. Furthermore, this technique enables us to record true current profiles flowing during an actual cardiac action potential. Of course, in the case of a drug acting on more than one ion current, such as rosiglitazone is, a series of peaks can be detected on the current trace, each of them corresponding to the fingerprint of an individual ion current [86]. Accordingly, the early outward current peak, shown in Fig. (7), arises when $\mathrm{I}_{\text {to }}$ is suppressed, while the inward deflection indicates a blockade of $\mathrm{I}_{\mathrm{Ca}}$. The late outward current peak, coincident with terminal repolarization of the canine action potential, is a mixture of $\mathrm{I}_{\mathrm{Kr}}$ plus $\mathrm{I}_{\mathrm{K} 1}$ [84]. In our case, however, it is likely caused by pure $\mathrm{I}_{\mathrm{Kr}}$ blockade, since - as we have previously shown - $\mathrm{I}_{\mathrm{K} 1}$ was not affected by $100 \mu \mathrm{M}$ rosiglitazone. As demonstrated in Fig. (7), rosiglitazone suppressed $\mathrm{I}_{\mathrm{to}}, \mathrm{I}_{\mathrm{Kr}}$, and $\mathrm{I}_{\mathrm{Ca}}$ under action potential voltage clamp conditions in a concentration-dependent and relatively reversible manner - in line with results of conventional voltage clamp experiments. The amplitudes of the three current peaks (early outward, inward, and late outward) are presented in Fig. (7) H-I.

\section{CLINICAL IMPLICATIONS}

The lowest concentration of rosiglitazone that caused statistically significant changes in our study was higher than those peak plasma levels obtained in patients. Peak plasma concentration of $0.8 \mu \mathrm{g} / \mathrm{ml}$ (corresponding to $2 \mu \mathrm{M}$ ) is typical in patients after receiving a single dose of $8 \mathrm{mg}$ rosiglitazone $[87,88]$. Therefore, it is not likely that normally dosed rosiglitazone can alter cardiac electrogenesis in healthy individuals. However, the probable proarrhythmic side effects of rosiglitazone could be not fully excluded in patients (elderly and/or diabetic) having cumulated cardiovascular risk factors (ischemic heart disease +hypertonia+hyperlipidaemia) and/or decreased elimination of the drug. Indeed, rosiglitazone was shown to increase propensity for ventricular fibrillation in ischemic pigs [36]. The ambiguous and contradictory clinical results [11, 12, 15, 66, 67] lead to restriction rather than market removal $[16,17,89]$. The cardiovascular safety profile of rosiglitazone is still an open question, because of the conflicting data on its risk/benefit ratio. The future of the drug probably will be determined by additional multicenter studies.

It is also very important to emphasize that the present results with rosiglitazone were obtained in healthy mammalian hearts, while rosiglitazone is usually used in diabetic patients. Considering that diabetes is known to induce marked remodelling in the set of cardiac ion currents in all studied mammalian species $[4-6,90]$ further studies in diabetic animal models should be performed.

\section{Acknowledgments}

This work was supported by the Hungarian Research Foundation (OTKA K68457, CNK-77855) and by Intramural Research Program of NIH/NAAA to P. Pacher. 


\section{ABBREVIATIONS}

AP

APA

APD

APD $_{90}$

PPAR $\gamma$

HF

HDC-KO mice

$\mathbf{I}_{\text {ss }}$

Ito

$\mathbf{I}_{\mathrm{Kr}}$

$\mathbf{I}_{\mathbf{C a}}$

$\mathbf{I}_{\mathbf{K} 1}$

TZD

T2DM

$\mathbf{V}_{\max }$ action potential

action potential amplitude

action potential duration

action potential duration at $90 \%$ level of repolarization

peroxisome-proliferator-activated receptor $\gamma$

heart failure

histidine decarboxylase knockout mice

steady-state outward current

transient outward $\mathrm{K}^{+}$current

rapid delayed rectifier $\mathrm{K}^{+}$current

L-type $\mathrm{Ca}^{2+}$ current

inward rectifier $\mathrm{K}^{+}$current

thiazolidinedione

type 2 diabetes mellitus

maximum velocity of depolarization

\section{References}

1. Gargiulo P, Jacobellis G, Vaccari V, Andreani D. Diabetic cardiomyopathy: Pathophysiological and clinical aspects. Diabetes Nutr Metab. 1998; 11:336-346.

2. Adeghate E, Kalász H, Veress G, Tekes K. Medicinal chemistry of drugs used in diabetic cardiomyopathy. Cur Med Chem. 2010; 17:517-551.

3. Shimoni Y, Firek L, Severson D, Giles W. Short-term diabetes alters $\mathrm{K}^{+}$currents in rat ventricular myocytes. Circ Res. 1994; 74:620-628. [PubMed: 8137498]

4. Magyar J, Rusznák Z, Szentesi P, Szúcs G, Kovács L. Action potentials and potassium currents in rat ventricular muscle during experimental diabetes. J Mol Cell Cardiol. 1992; 24:841-853. [PubMed: 1433314]

5. Pacher P, Ungvári Z, Nánási PP, Kecskeméti V. Electrophysiological changes in rat ventricular and atrial myocardium at different stages of experimental diabetes. Acta Physiol Scand. 1999; 66:7-13. [PubMed: 10372973]

6. Lengyel, Cs; Virág, L.; Kovács, PP.; Kristóf, A.; Pacher, P.; Kocsis, E.; Koltay, ZM.; Nánási, PP.; Tóth, M.; Kecskeméti, V.; Papp, JG.; Varró, A.; Jost, N. Role of slow delayed rectifier K+-current in QT prolongation in the alloxan-induced diabetic rabbit heart. Acta Physiol. 2008; 192:359-368.

7. Nathan DM, Buse JB, Davidson MB, Ferrannini E, Holman RR, Sherwin R, Zinman B. Management of hyperglycaemia in type 2 diabetes mellitus: a consensus algorithm for the initiation and adjustment of therapy: Update regarding the thiazolidinediones. Diabetologia. 2008; 51:8-11. [PubMed: 18026926]

8. Tonelli J, Li W, Kishore P, Pajvani UB, Kwon E, Weaver C, Scherer PE, Hawkins M. Mechanisms of early insulin-sensitizing effects of thiazolidinediones in type 2 diabetes. Diabetes. 2004; 53:1621-1629. [PubMed: 15161771]

9. Waugh J, Keating GM, Plosker GI, Easthope S, Robinson DM. Pioglitazone: a review of its use in type diabetes mellitus. Drugs. 2006; 66:85-109. [PubMed: 16398569]

10. Kahn SE, Haffner SM, Heise MA, Herman WH, Holman RR, Jones NP, Kravitz BG, Lachin JM, O’Neill MC, Zinman B, Viberti G. ADOPT Study Group. Glycemic durability of rosiglitazone, metformin or glyburide monotherapy. N Engl J Med. 2006; 355:2427-2443. [PubMed: 17145742] 
11. Krentz A. Thiazolidinediones: effects on the development and progression of type 2 diabetes and associated vascular complications. Diabetes Metab Res Rev. 2009; 25:112-126. [PubMed: 19219860]

12. Kaul S, Diamond GA. Diabetes: Breaking news! Rosiglitazone and cardiovascular risk. Nat Re v Cardiol. 2010; 12:670-672.

13. Lago RM, Singh PP, Nesto RW. Congestive heart failure and cardiovascular death in patients with prediabetes and type 2 diabetes given thiazolidinediones: a meta-analysis of randomized clinical trials. Lancet. 2007; 370:1129-1136. [PubMed: 17905165]

14. Singh S, Loke YK, Furberg CD. Thiazolidinediones and heart failure: A teleo-analysis. Diabetes Care. 2007; 30:2148-2153. [PubMed: 17536074]

15. Nissen SE, Wolski K. Effect of rosiglitazone on the risk of myocardial infarction and death from cardiovascular causes. N Engl J Med. 2007; 356:2457-2471. [PubMed: 17517853]

16. [accessed January 8th 2011] www1: http://www.ema.europa.eu/docs/en_GB/document_library/Press_release/2010/09/ WC500096996.pdf

17. [Accessed January 8th 2011] www2: http://www.fda.gov/Drugs/DrugSafety/PostmarketDrugSafetyInformationforPatientsandProviders/ ucm226956.htm

18. Fujita T, Sugiyama Y, Taketomi S, Sohda T, Kawamatsu Y, Iwatsuka H, Suzuoki Z. Reduction of insulin resistance in obese and/or diabetic animals by 5-[4-(1-methylcyclohexylmethoxy)benzyl]thiazolidine-2,4-dione (ADD-3878; U-63,287, ciglitazone), a new antidiabetic agent. Diabetes. 1983; 32:604-610.

19. Day C. Thiazolidinediones: a new class of antidiabetic drugs. Diabetic Med. 1999; 16:179-192. [PubMed: 10227562]

20. Forman BM, Evans RM. The peroxisome proliferator-activating receptors ligands and activators. Ann New York Acad Sci. 1996; 804:266-275. [PubMed: 8993549]

21. Latinffe N, Vamecq Y. Peroxisome proliferator and peroxisome proliferator activated receptors as regulators of lipid metabolism. Biochimie. 1999; 79:81-94.

22. Blaschke F, Takata Y, Caglayan E, Law RE, Hsueh WA. Obesity, peroxisome proliferatoractivated receptor, and atherosclerosis in type 2 diabetes. Arterioscler Thromb Vasc Biol. 2006; 26:28-40. [PubMed: 16239592]

23. Hoffman C, Lorentz K, Cola JR. Glucose transport deficiency in diabetic animals is corrected by treatment with the oral antihyperglycemic agent pioglitazone. Endocrinology. 1991; 129:19151925. [PubMed: 1915075]

24. Gitlin N, Julie NL, Spurr CL, Lim KN, Juarbe HM. Two cases of severe clinical and histologic hepatotoxicity associated with troglitazone. Ann Intern Med. 1998; 129:36-38. [PubMed: 9652997]

25. Larsen PJ, Lykkegaard K, Larsen LK, Fleckner J, Sauerberg P, Wassermann K, Wulff EM. Dissociation of antihyperglycaemic and adverse effects of partial peroxisome proliferatoractivated receptor(PPAR- $\gamma$ ) agonist balaglitazone. Europ J Pharmacol. 2008; 596:173-179.

26. Acton JJ. $3^{\text {rd; }}$ Akiyama, T.E., Chang, C.H., Colwell, I., Debenham, S., Doebber, T., Einstein, M., Liu, K., McCann, M.E., Moller, D.E., Muise, E.S., Tan, Y., Thompson, J.R., Wong, K.K., Wu, M., Xu, L., Meinke, P.T., Berger, J.P., Wood, H.B. Discovery of (2R)-2-(3-(3-[(4-Methoxyphenyl)carbonyl]-2methyl-6(trifluoromethoxy)-1H-indol-yl)phenoxy)butanoic Acid (MK-0533): A Novel Selective Peroxisome Proliferator-Activated Receptor $\gamma$ Modulator for the Treatment of Type 2 Diabetes Mellitus with a Reduced Potential to Increase Plasma and Extracellular Fluid Volume. J Med Chem. 2009; 52:3846-3854. [PubMed: 19507861]

27. Seto S, Okada K, Kiyota K, Isogai S, Iwago M, Shinozaki T, Kitamura Y, Kohno Y, Murakami K. Design, Synthesis, and Structure-Activity Relationship Studies of Novel 2,4,6-Trisubstituted-5pirimidinecarboxykic Acid as Peroxisome Proliferator-Activated Receptor $\gamma$ (PPAR $\gamma$ ) Partial Agonists with Comparable Antidiabetic Efficacy to Rosiglitazone. J Med Chem. 2010; 53:50125024. [PubMed: 20527969] 
28. Fujiwara T, Yoshioka S, Yoshioka T, Ushiyama I, Horikoshi H. Characterization of new oral antidiabetic agent CS-045. Studies in KK and ob/ob mice and Zucker fatty rats. Diabetes. 1988; 37:1549-1558. [PubMed: 3053303]

29. Oakes ND, Kennedy CJ, Jenkins AB, Laybutt DR, Chisholm DJ, Kraegen EW. A new antidiabetic agent, BRL 49653; reduces lipid availability and improves insulin action and glucoregulation in the rat. Diabetes. 1994; 43:1203-1010. [PubMed: 7926289]

30. Fujiwara T, Okuno A, Yoshioka S, Horikoshi H. Suppression of hepatic gluconeogenesis in longterm Troglitazone treated diabetic KK and C57BL/KsJ-db/db mice. Metabolism. 1995; 44:486490. [PubMed: 7723671]

31. Young IH. Insulin resistance and the effects of thiazolidinediones on cardiac metabolism. Ann J Med. 2003; 115:75S-80S.

32. Kecskemeti V, Bagi Zs, Pacher P, Posa I, Kocsis E, Koltai MZs. New trends in the development of oral antidiabetic drugs. Current Medicinal Chemistry. 2002; 8:53-73. [PubMed: 11860348]

33. Yki-Jarvinen H. Thiazolidinediones. New Eng J Med. 2004; 351:1106-1118. [PubMed: 15356308]

34. Sung BH, Izzo JL Jr, Dandona P, Wilson MF. Vasodilatory effects of troglitazone improve blood pressure at rest and during mental stress in type 2 diabetes mellitus. Hypertension. 1999; 34:8388. [PubMed: 10406828]

35. Walker AB, Chattington PD, Buckingham RE, Williams G. The thiazolidinedione rosiglitazone (BRL-49653) lowers blood pressure and protects against impairment of endothelial function in Zucker fatty rats. Diabetes. 1999; 48:1448-1453. [PubMed: 10389852]

36. Khandoudi N, Delerive P, Berrebi-Bertrand I, Buckingham RE, Staels B, Bril A. Rosiglitazone, a peroxisome proliferator-activated receptor- $\gamma$, inhibits the Jun NH2-terminal kinase activating protein 1 pathway and protects the heart from inschemic/reperfusion injury. Diabetes. 2002; 51:1507-1514. [PubMed: 11978649]

37. Sundararajan S, Landreth GE. Antiinflammatory properties of PPAR-gamma agonists following ischemia. Drug News Perspect. 2004; 4:229-236. [PubMed: 15334171]

38. Sarafidis PA, Nilsson PM. The effects of thiazolidinediones on blood pressure levels - a systematic review. Blood Press. 2006; 15:135-150. [PubMed: 16864155]

39. Goldberg RB, Kendall DM, Deeg MA, Buse JB, Zagar AJ, Pinaire JA, Tan MH, Khan MA, Perez AT, Jacober SJ. GLAI Study Investigators. A comparison of lipid and glycemic effects of pioglitazone and rosiglitazone in patients with type 2 diabetes and dyslipidemia. Diabetes Care. 2005; 28:1547-1554. [PubMed: 15983299]

40. Deeg MA, Buse JB, Goldberg RB, Kendall DM, Zagar AJ, Jacober SJ, Khan MA, Perez AT, Tan MH. GLAI Study Investigators. Pioglitazone and rosiglitazone have different effects on serum lipoprotein particle concentrations and sizes in patients with type 2 diabetes and dyslipidemia. Diabetes Care. 2007; 30:2458-2464. [PubMed: 17595355]

41. Haffner SM, Greenberg AS, Weston WM, Chen H, Williams K, Freed MI. Effect of rosiglitazone treatment on nontraditional markers of cardiovascular disease in patients with type 2 diabetes mellitus. Circulation. 2002; 106:679-684. [PubMed: 12163427]

42. Satoh N, Ogawa Y, Usui T, Tagami T, Kono S, Uesugi H, Sugiyama H, Sugawara A, Yamada K, Shimatsu A, Kuzuya H, Nakao K. Antiatherogenic effect of pioglitazone in type 2 diabetic patients irrespective of the responsiveness to its antidiabetic effect. Diabetes Care. 2003; 26:2493-2499. [PubMed: 12941708]

43. Derosa G, Cicero AF, Gaddi A, Ragonesi PD, Piccinni MN, Fogari E, Salvadeo S, Ciccarelli L, Fogari R. A comparison of the effects of pioglitazone and rosiglitazone combined with glimepiride on prothrombotic state in type 2 diabetic patients with the metabolic syndrome. Diabetes Res Clin Pract. 2005; 69:5-13. [PubMed: 15955382]

44. Matsuzawa Y. Adiponectin: Identification, physiology and clinical relevance in metabolic and vascular disease. Atheroscler Suppl. 2005; 6:7-14. [PubMed: 15823491]

45. Marx N, Walcher D. Vascular effects of PPARgamma activators - from bench to bedside. Prog Lipid Res. 2007; 46:283-296. [PubMed: 17637478]

46. Sarafidis PA, Bakris GL. Protection of the kidney by thiazolidinediones: An assessment from bench to bedside. Kidney Int. 2006; 70:1223-1233. [PubMed: 16883325] 
47. Yue TL, Bao W, Gu JL, Cui J, Tao L, Ma XL, Ohlstein EH, Jucker BM. Rosiglitazone treatment in Zucker diabetic Fatty rats is associated with ameliorated cardiac insulin resistance and protection from ischemia/reperfusion-induced myocardial injury. Diabetes. 2005; 54:554-562. [PubMed: 15677515]

48. Luo Y, Yin W, Signore AP, Zhang F, Hong Z, Wang S, Graham SH, Chen J. Neuroprotection against focal ischemic brain injury by the peroxisome proliferator-activated receptor-gamma agonist rosiglitazone. J Neurochem. 2006; 97:435-448. [PubMed: 16539667]

49. Ye Y, Lin Y, Atar S, Huang MH, Perez-Polo JR, Uretsky BF, Birnbaum Y. Myocardial protection by pioglitazone, atorvastatin, and their combination: mechanisms and possible interactions. Am J Physiol Heart Circ Physiol. 2006; 291:1158-1169.

50. Mazzone T, Meyer PM, Feinstein SB, Davidson MH, Kondos GT, D’Agostino RB, Perez A, Provost JC, Haffner SM. Effect of pioglitazone compared with glimepiride on carotid intimamedia thickness in type 2 diabetes: a randomized trial. JAMA. 2006; 296:2572-2581. [PubMed: 17101640]

51. Stocker DJ, Taylor AJ, Langley RW, Jezior MR, Vigersky RA. A randomized trial of the effects of rosiglitazone and metformin on inflammation and subclinical atherosclerosis in patients with type 2 diabetes. Am Heart J. 2007; 153:445.e1-6. [PubMed: 17307426]

52. Nissen SE, Nicholls SJ, Wolski K, Nesto R, Kupfer S, Perez A, Jure H, De Larochellière R, Staniloae CS, Mavromatis K, Saw J, Hu B, Lincoff AM, Tuzcu EM. PERISCOPE Investigators. Comparison of pioglitazone vs glimepiride on progression of coronary atherosclerosis in patients with type 2 diabetes. The PERISCOPE randomized controlled trial. JAMA. 2008; 299:1561-1573. [PubMed: 18378631]

53. Gilles RD. Effects of Ramipril and Rosiglitazone on Cardiovascular and Renal Outcomes in People with Impaired Glucose Tolerance or Impaired Fasting Glucose: A Randomized, Controlled Trial. Results of the Diabetes REduction Assessment with ramipril and rosiglitazone Medication (DREAM) study. Diabetes Care. 2008

54. McGuire DK, Inzucchi SE. Drugs for the treatment of diabetes mellitus. Part I: Thiazolidinediones and their evolving cardiovascular implications. Circulation. 2008; 117:440-449. [PubMed: 18212301]

55. Vasudevan AR, Balasubramanyam A. Thiazolidinediones: a review of their mechanisms of insulin sensitization, therapeutic potential, clinical efficacy, and tolerability. Diabetes Technol Ther. 2004; 6:850-863. [PubMed: 15684639]

56. Diep QN, El Mabrouk M, Cohn JS, Endemann D, Amiri F, Virdis A, Neves MF, Schiffrin EL. Structure, endothelial function, cell growth, and inflammation in blood vessels of angiotensin IIinfused rats: role of peroxisome proliferator-activated receptor-gamma. Circulation. 2002; 105:2296-2302. [PubMed: 12010913]

57. Guan Y, Hao C, Cha DR, Rao R, Lu W, Kohan DE, Magnuson MA, Redha R, Zhang Y, Breyer MD. Thiazolidinediones expand body fluid volume through PPARgamma stimulation of ENaCmediated renal salt absorption. Nat Med. 2005; 11:861-866. [PubMed: 16007095]

58. Zhang H, Zhang A, Kohan DE, Nelson RD, Gonzalez FJ, Yang T. Collecting duct- specific deletion of peroxisome proliferator-activated receptor gamma blocks thiazolidinedione-induced fluid retention. Proc Natl Acad Sci USA. 2005; 102:9406-9411. [PubMed: 15956187]

59. Erdmann E, Wilcox RG. Weighing up the cardiovascular benefits of thiazolidinedione therapy: the impact of increased risk of heart failure. Eur Heart J. 2008; 29:12-20. [PubMed: 18167366]

60. Lincoff AM, Wolski K, Nicholls SJ, Nissen SE. Pioglitazone and risk of cardiovascular events in patients with type 2 diabetes mellitus: a meta-analysis of randomized trials. JAMA. 2007; 298:1180-1188. [PubMed: 17848652]

61. Giles TD, Miller AB, Elkayam U, Bhattacharya M, Perez A. Pioglitazone and heart failure: results from a controlled study in patients with type 2 diabetes mellitus and systolic dysfunction. J Card Fail. 2008; 14:445-452. [PubMed: 18672190]

62. Nesto RW, Bell D, Bonow RO, Fonseca V, Grundy SM, Horton ES, Le Winter M, Porte D, Semenkovich CF, Smith S, Young LH, Kahn R. Thiazolid- inedione use, fluid retention, and congestive heart failure: a consensus statement from the American Heart Association and American Diabetes Association. Diabetes Care. 2004; 27:256-263. [PubMed: 14693998] 
63. Singh S, Loke YK, Furberg CD. Long-term risk of cardiovascular events with rosiglitazone: a meta-analysis. JAMA. 2007; 298:1189-1195. [PubMed: 17848653]

64. Erdmann E, Spanheimer R, Charbonnel B. PROactive Study Investigators. Pioglitazone and the risk of cardiovascular events in patients with Type 2 diabetes receiving concomitant treatment with nitrates, renin-angiotensin system blockers, or insulin: results from the PROactive study (PROactive 20). J Diabetes. 2010; 2:212-220. [PubMed: 20923486]

65. Erdmann E, Charbonnel B, Wilcox R. Thiazolidinediones and cardiovascular risk- A question of balances. Curr Cardiol Rev. 2009; 5:155-165. [PubMed: 20676274]

66. Rosen JC. The rosiglitazone story: lessons from an FDA Advisory Committee meeting. N Engl J Med. 2007; 357:844-846. [PubMed: 17687124]

67. Mannucci E, Monami M. Is the evidence from clinical trials for cardiovascular risk or harm for glitazones convincing? Curr Diab Rep. 2009; 5:342-347. [PubMed: 19793503]

68. Lu L, Reiter MJ, Xu Y, Chicco A, Greyson CR, Schwartz GG. Thiazolidinedione drugs block cardiac $\mathrm{K}_{\mathrm{ATP}}$ channels and may increase propensity for ischemic ventricular fibrillation in pigs. Diabetologia. 2008; 51:675-685. [PubMed: 18251006]

69. Pancani T, Phelps JT, Searcy JL, Kilgore MW, Chen KC, Porter NM, Thibault O. Distinct modulation of voltage-gated and ligand-gated $\mathrm{Ca}^{2+}$ currents by PPAR-gamma agonists in cultured hipocampal neurons. J Neurochem. 2009; 109:1800-1811. [PubMed: 19453298]

70. Pavlov TS, Levchenko VL, Karpushev AV, Vandewalle A, Staruschenko A. Peroxisome proliferators-activated receptor gamma antagonists decrease $\mathrm{Na}^{+}$transport via the epithelial $\mathrm{Na}^{+}$ channel. Mol Pharmacol. 2009; 76:1333-1340. [PubMed: 19752200]

71. Mishra SK, Aaronson PI. Differential block by troglitazone and rosiglitazone of glibenclamidesensitive $\mathrm{K}^{+}$current in rat aorta myocytes. Eur J Pharmacol. 1999; 368:121-125. [PubMed: 10611472]

72. Knock GA, Mishra SK, Aaronson PI. Differential effects of insulin-sensitizers troglitazone and rosiglitazone on ion currents in rat vascular smooth muscle. Eur J Pharmacol. 1999; 368:103-109. [PubMed: 10096775]

73. Nakajima T, Iwasawa K, Oonuma H, Imuta H, Hazama H, Asano M, Morita T, Nakamura F, Suzuki J, Suzuki S, Kawakami Y, Omata M, Okuda Y. Troglitazone inhibits voltage-dependent calcium currents in guinea pig cardiac myocytes. Circulation. 1999; 99:2942-2950. [PubMed: 10359740]

74. Katoh Y, Hashimoto S, Kimura J, Watanabe T. Inhibitory action of troglitazone, an insulinsensitising agent, on the calcium current in cardiac ventricular cells of guinea pig. Jpn J Pharmacol. 2000; 82:102-109. [PubMed: 10877527]

75. Arikawa M, Takahashi N, Kira T, Hara M, Saikawa T, Sakata T. Enhanced inhibition of L-type calcium currents by troglitazone in streptozotocin-induced diabetic rat cardiac ventricular myocytes. Br J Pharmacol. 2002; 136:803-810. [PubMed: 12110604]

76. Arikawa M, Takahashi N, Kira T, Hara M, Yoshimatsu H, Saikawa T. Attenuated inhibition of Ltype calcium currents by troglitazone in fructose-fed rat cardiac ventricular myocytes. $\mathrm{J}$ Cardiovasc Pharmacol. 2004; 44:109-116. [PubMed: 15175565]

77. Ikeda S, Watanabe T. Effects of troglitazone and pioglitazone on the action potentials and membrane currents of rabbit ventricular myocytes. Eur J Pharmacol. 1998; 357:243-250. [PubMed: 9797043]

78. Strichartz G, Cohen I. $\mathrm{V}_{\max }$ as a measure of GNa in nerve and cardiac membranes. Biophys J. 1978; 23:153-156. [PubMed: 667304]

79. Kavak S, Emre M, Tetiker T, Kavak T, Kolcu Z, Günay I. Effects of rosiglitazone on altered electrical left ventricular papillary muscle activities of diabetic rat. Naunyn Schmiedebergs Arch Pharmacol. 2008; 376:415-421. [PubMed: 18097651]

80. Brunet S, Aimond F, Li H, Guo W, Eldstrom J, Fedida D, Yamada KA, Nerbonne JM. Heterogeneous expression of repolarizing, voltage-gated $\mathrm{K}^{+}$currents in adult mouse ventricles. Journal of Physiology. 2004; 559:103-120. [PubMed: 15194740]

81. Quintana FJ, Buzas E, Prohaszka Z, Biro A, Kocsis J, Fust G, Falus A, Cohen IR. Knock-out of the histidine decarboxylase gene modifies the repertoire of natural autoantibodies. Journal of Autoimmunity. 2004; 22:297-305. [PubMed: 15120753] 
82. Szebeni A, Falus A, Kecskeméti V. Electrophysiological characteristics of heart ventricular papillary muscles in diabetic histidine decarboxylase knockout and wild-type mice. J Interv Card Electrophysiol. 2009; 26:155-158. [PubMed: 19731003]

83. Wilson KD, Li Z, Wagner R, Yue P, Tsao P, Nestorova G, Huang M, Hirschberg DL, Yock PG, Qertermous T, Wu JC. Transcriptome alteration in the diabetic heart by rosiglitazone: implications for cardiovascular mortality. PloS One. 2008; 3:e2609. [PubMed: 18648539]

84. Jeong I, Choi B, Hahn S. Rosiglitazone inhibits $\mathrm{K}_{(\mathrm{v})} 4.3$ potassium channels by open-channel block and acceleration of closed-state inactivation. Br J Pharmacol. 201110.1111/j. 1476-5381.2011.01210.x

85. Bányász T, Fülöp L, Magyar J, Szentandrássy N, Varró A, Nánási PP. Endocardial versus epicardial differences in L-type calcium current in canine ventricular myocytes studied by action potential voltage clamp. Cardiovasc Res. 2003; 58:66-75. [PubMed: 12667947]

86. Bányász T, Magyar J, Szentandrássy N, Horváth B, Birinyi P, Szentmiklósi J, Nánási PP. Action potential clamp fingerprints of $\mathrm{K}^{+}$currents in canine cardiomyocytes: their role in ventricular repolarization. Acta Physiol. 2007; 190:189-198.

87. Park JY, Kim KA, Shin JG, Lee KY. Effect of ketoconazole on the pharmacokinetics of rosiglitazone in healthy subjects. Br J Clin Pharmacol. 2004; 58:397-402. [PubMed: 15373932]

88. Wittayalertpanya S, Chompootaveep S, Thaworn N, Khemsri W, Intanil N. Pharmacokinetic and bioequivalence study of an oral $8 \mathrm{mg}$ dose of rosiglitazone tablets in Thai healthy volunteers. $\mathrm{J}$ Med Assoc Thai. 2010; 93:722-728. [PubMed: 20572378]

89. Kaul S, Bolger AF, Herrington D, Giugliano RP, Eckel RH. American Heart Association; American College Of Cardiology Foundation. Thiazolidinedione drugs and cardiovascular risks: a science advisory from the American Heart Association and American College Of Cardiology Foundation. J Am Coll Cardiol. 2010; 55:1885-1894. [PubMed: 20413044]

90. Lengyel C, Virág L, Bíró T, Jost N, Magyar J, Biliczki P, Kocsis E, Skoumal R, Nánási PP, Tóth M, Kecskeméti V, Papp JG, Varró A. Diabetes mellitus attenuates the repolarization reserve in mammalian heart. Cardiovasc Res. 2007; 73:512-520. [PubMed: 17182020] 
<smiles>CC1(COc2ccc(CC3SC(=O)NC3=O)cc2)CCCCC1</smiles><smiles>Cc1c(C)c2c(c(C)c1O)CCC(C)(COc1ccc(CC3SC(=O)NC3=O)cc1)O2</smiles><smiles>CCc1ccc(CCOc2ccc(CC3SC(=O)NC3=O)cc2)nc1</smiles><smiles>O=C1NC(=O)C(Cc2ccc3c(c2)CCC(Cc2ccccc2)O3)S1</smiles>

Englitazone<smiles>[R10]CCN(C)c1ccccn1</smiles><smiles>Cc1oc(-c2ccccc2)nc1CCC(=O)c1ccc(CC2SC(=O)NC2=O)cc1</smiles>

Fig. 1.

Chemical structure of thiazolidinediones. 
<smiles>O=C1NC(=O)C(Cc2ccc(OCc3nc4ccccc4c(=O)[nH]3)cc2)S1</smiles><smiles>CC[C@H](Oc1cccc(-n2c(C)c(C(=O)c3ccc(OC)cc3)c3ccc(OC(F)(F)F)cc32)c1)C(=O)O</smiles><smiles>CSc1nc(SCc2ccccc2)c(C(=O)O)c(SCc2ccccc2)n1</smiles>

Fig. 2.

Chemical structures of some partial PPAR $\gamma$ receptor agonists, like balaglitazone, MK-0533 and Compound $\mathbf{5 0}$. 

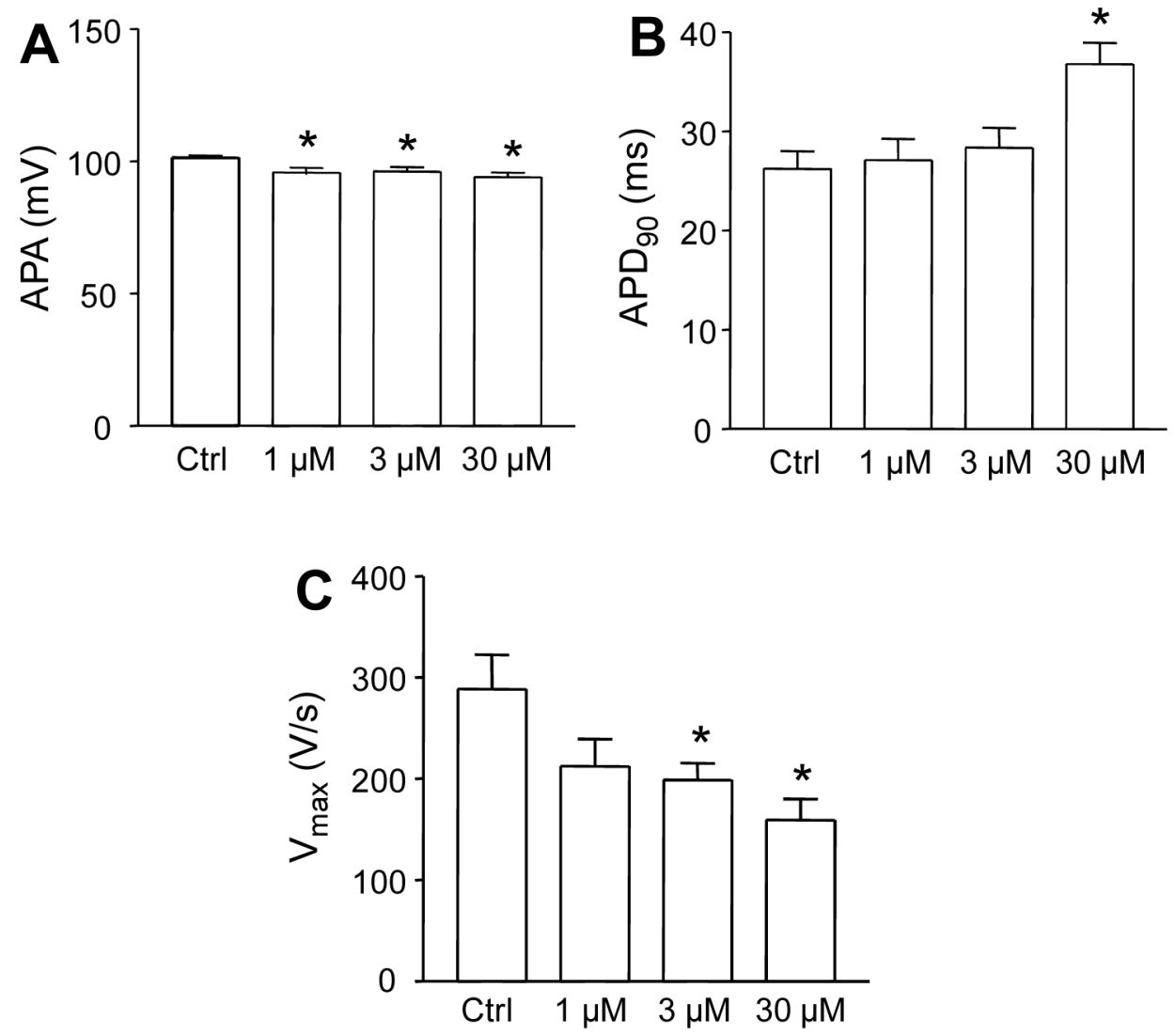

Fig. 3.

Electrophysiological parameters of isolated right ventricular papillary muscles in rat under control (Ctrl) conditions and following rosiglitazone treatment $(1,3$, and $30 \mu \mathrm{M})$. Columns and bars represent mean \pm SEM values of APA $(A, n=15), \operatorname{APD}_{90}(\mathbf{B}, n=15)$ and $\mathrm{V}_{\max }(\mathbf{C}$, $n=15$ ) measurements, $n=$ number of animals. ANOVA and Student's $t$ test were used for statistical comparisons $(* \mathrm{p}<0.05$ significant difference from control). 

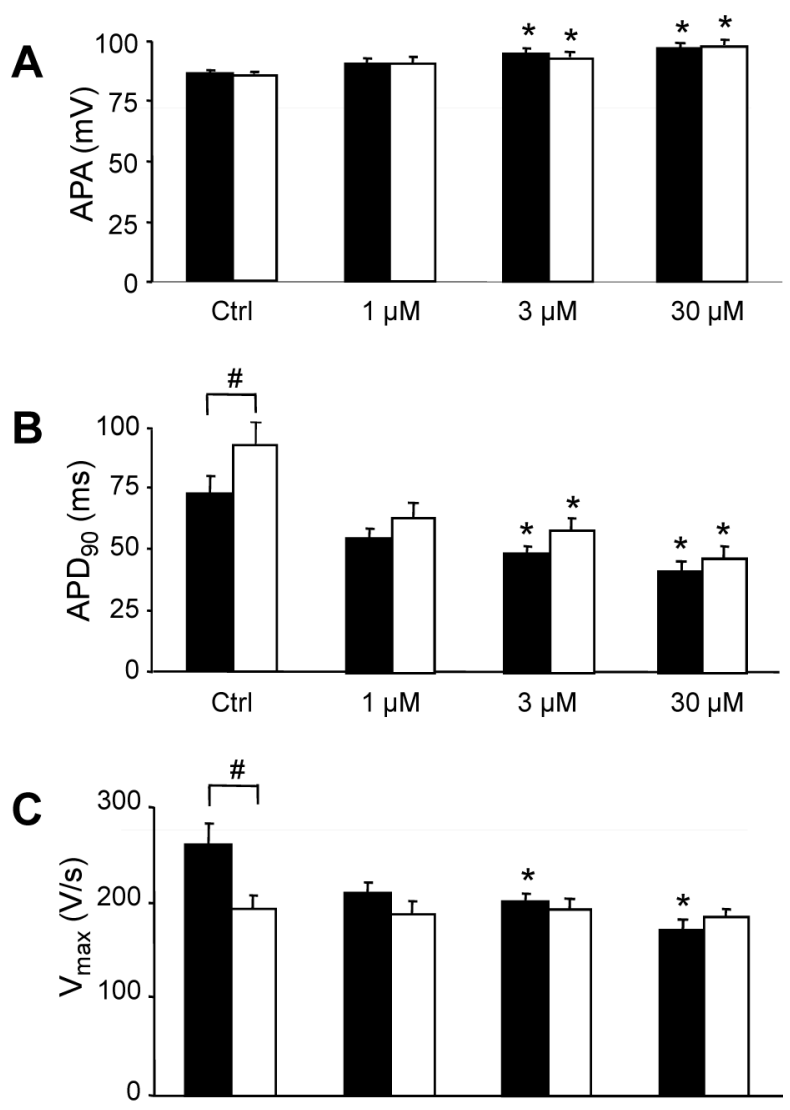

Wild type $\square$ HDC-KO

Fig. 4.

Comparison of electrophysiological parameters of isolated right ventricular papillary muscles from wild-type (WT) and histidine decarboxylase knockout (HDC-KO) mice under control (Ctrl) conditions and following rosiglitazone treatment (1, 3, and $30 \mu \mathrm{M})$. Columns and bars represent mean \pm SEM values of APA $(\mathbf{A}, n=15), \operatorname{APD}_{90}(\mathbf{B}, n=15)$ and $\mathrm{V}_{\max }(\mathbf{C}$, $\mathrm{n}=15$ ) measurements. ANOVA and Student's t test were used for statistical comparisons $(* \mathrm{p}<0.05$ significant difference from control, $\# \mathrm{p}<0.05$ significant difference between control WT and HDC-KO group). 

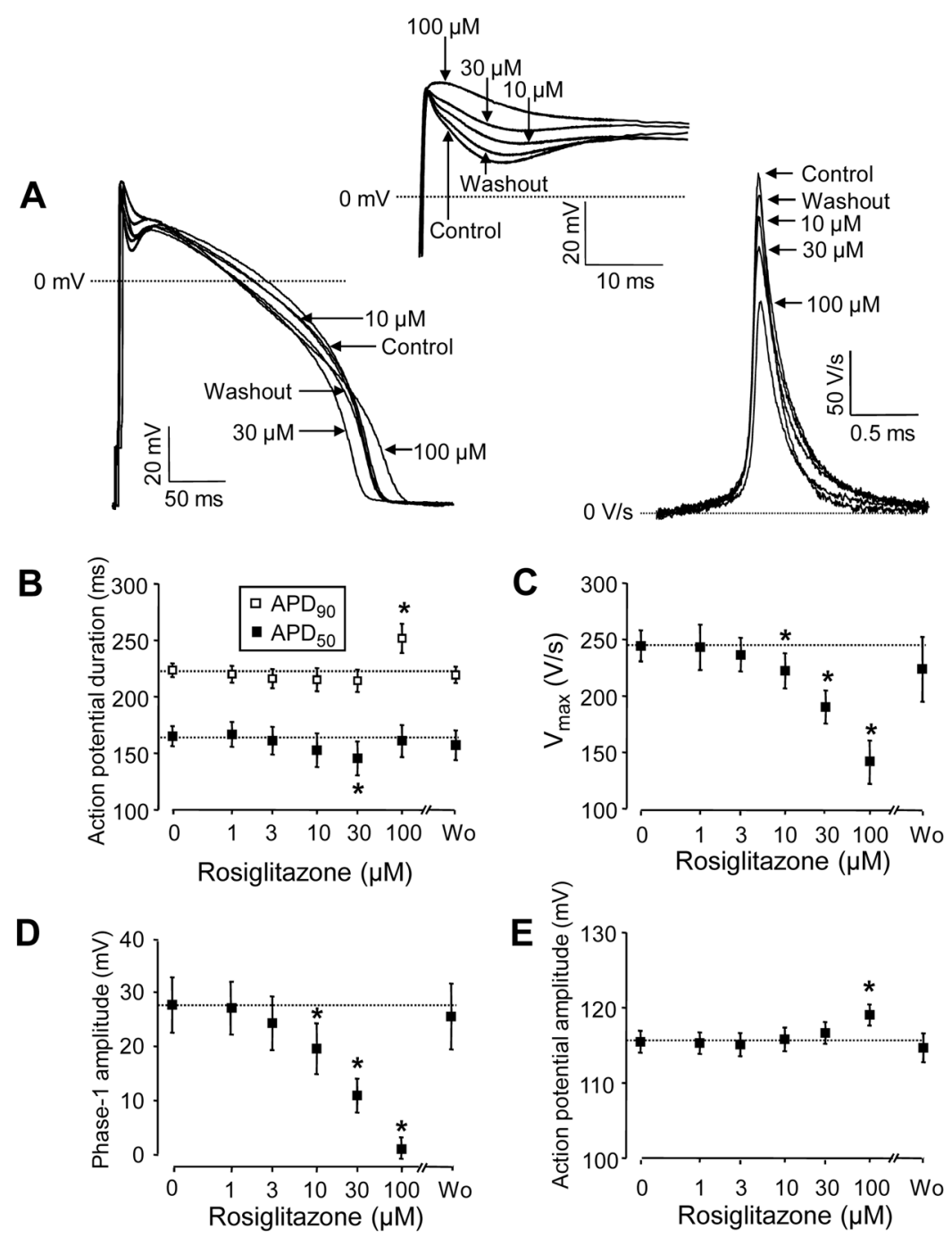

Fig. 5.

A: Representative set of superimposed action potentials showing the cumulative concentration-dependent effects rosiglitazone on action potential configuration. Early events of the action potential are enlarged in the inset, the first time-derivatives of action potential upstrokes are depicted on the right. The action potentials were superimposed so as to match their upstrokes. B, C, D, E: Cumulative concentration-dependent effects of rosiglitazone on action potential duration measured at $50 \%\left(\mathrm{APD}_{50}\right)$ and $90 \%\left(\mathrm{APD}_{90}\right)$ level of repolarization, the maximum rate of depolarization $\left(\mathrm{V}_{\max }\right)$, amplitude of phase-1 repolarization, and the action potential amplitude, respectively. Phase-1 amplitude was determined as a difference of overshoot potential and the deepest point of the incisura. Each concentration of rosiglitazone was superfused for $3 \mathrm{~min}$, the washout (Wo) lasted for 10 min. Symbols and bars represent mean \pm SEM values obtained in 8 myocytes, asterisks denote significant $(\mathrm{P}<0.05)$ changes from pre-drug control values, which are also indicated by dotted lines. 

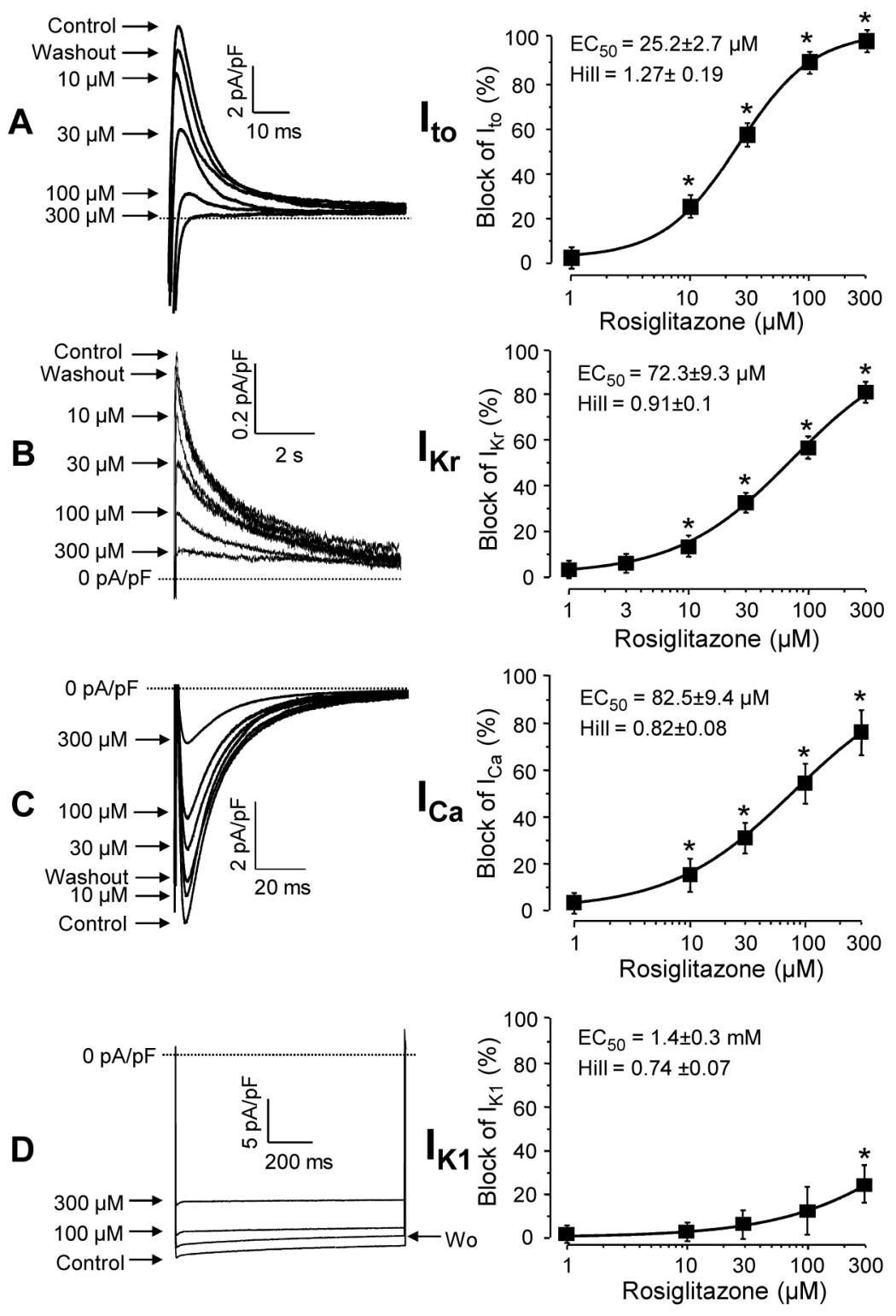

Fig. 6.

Cumulative concentration-dependent effects of rosiglitazone on $\mathrm{I}_{\mathrm{to}}(\mathbf{A}, \mathrm{n}=5), \mathrm{I}_{\mathrm{Kr}}(\mathbf{B}, \mathrm{n}=5)$, $\mathrm{I}_{\mathrm{Ca}}(\mathbf{C}, \mathrm{n}=6)$, and $\mathrm{I}_{\mathrm{K} 1}(\mathbf{D}, \mathrm{n}=4)$ measured using conventional voltage clamp. Left panels show superimposed current traces recorded before and after superfusion with increasing concentrations of rosiglitazone, followed by a washout. $\mathrm{I}_{\mathrm{Ca}}$ and $\mathrm{I}_{\text {to }}$ were recorded as current peaks arising during the test pulse (difference between the peak and pedestal value), $\mathrm{I}_{\mathrm{K} 1}$ was determined as absolute values measured at the end of each test pulse, while $\mathrm{I}_{\mathrm{Kr}}$ was evaluated as a tail current, obtained upon repolarization to the holding potential. Average data showing concentration-dependent blocking effects of rosiglitazone are presented on the right panels as Hill plots. $\mathrm{I}_{\mathrm{Ca}}$ and $\mathrm{I}_{\mathrm{Ks}}$ were blocked by $5 \mu \mathrm{M}$ nifedipine and $1 \mu \mathrm{M}$

HMR-1556, respectively, when measuring $\mathrm{I}_{\mathrm{to}}$ and $\mathrm{I}_{\mathrm{Kr}}$. During the measurement of $\mathrm{I}_{\mathrm{Ca}} 3 \mathrm{mM}$ 4-aminopyridine and $1 \mu \mathrm{M}$ E4031 were applied in order to block $\mathrm{K}^{+}$currents. Symbols and bars indicate mean values \pm SEM, asterisks indicates significant $(\mathrm{P}<0.05)$ changes from control. 
A

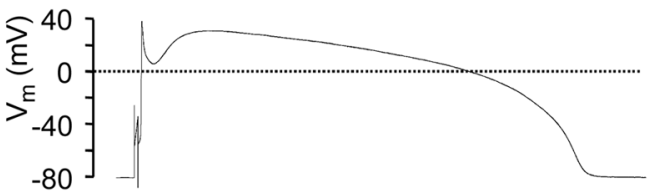

B

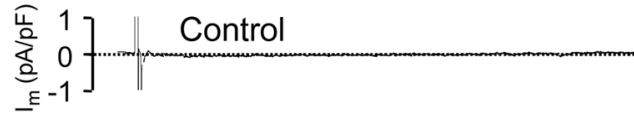

C

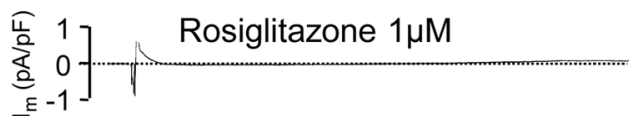

D

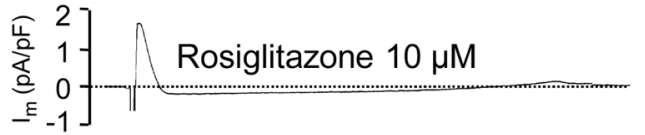

E

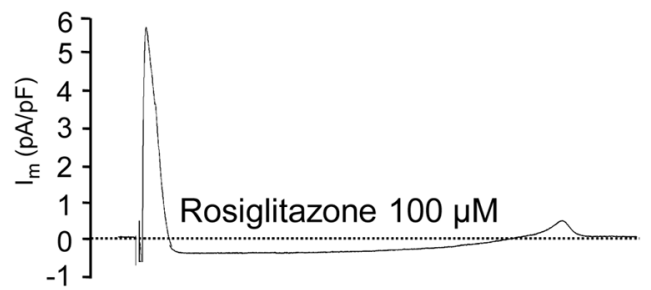

$\mathbf{F}$

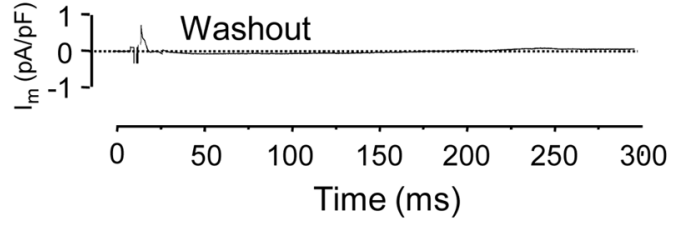

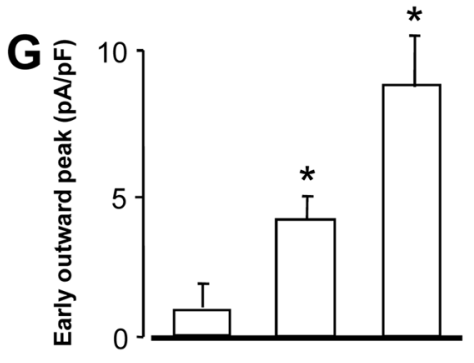
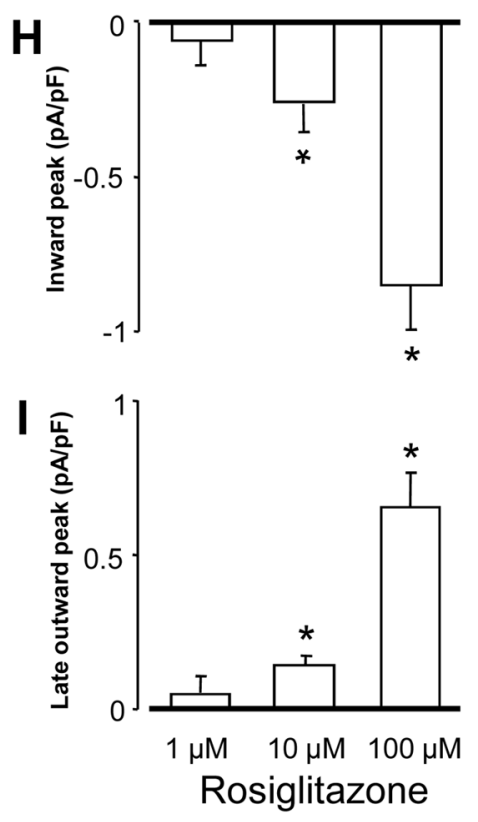

Fig. 7.

Effects of 1,10 , and $100 \mu \mathrm{M}$ rosiglitazone on ion currents under action potential voltage clamp conditions. Representative records of a command signal (A), and the underlying current traces obtained before $(\mathbf{B})$, in the presence $(\mathbf{C}-\mathbf{E})$, and after washout of rosiglitazone (F). Since ion currents were obtained from the same cell that provided the command action potential, the pre-drug current record was a horizontal line at the zero level. The post-drug difference currents have been inverted in order to present the currents with their conventional polarity. Dotted lines indicate zero current level for each trace. G-I: Average results obtained with rosiglitazone on the early outward current peak (indicator of $\mathrm{I}_{\mathrm{to}}, \mathbf{G}$ ), inward current peak (indicator of $\mathrm{I}_{\mathrm{Ca}}, \mathbf{H}$ ), and the late out-ward current peak (indicator of $\mathrm{I}_{\mathrm{Kr}}$ dominantly, I) in 5 myocytes. Columns and bars are means \pm SEM, asterisks denote significant $(\mathrm{P}<0.05)$ changes from control. 